DOI: $10.22363 / 2312-9220-2021-26-4-649-655$

УДК 659.4:1

Research article / Научная статья

\title{
Transdiscourse as a Concept of Digital Worlds
}

\author{
Anna A. Kostikova , Sergey A. Spartak \\ Lomonosov Moscow State University, \\ 1 Leninsky Gory, Moscow, 119234, Russian Federation \\ $\bowtie$ akostikova04@ya.ru
}

\begin{abstract}
The paper presents the current transformations of media culture in the conditions of crucial digitalization of society. Everyday life is fundamentally mediatized and this process is beyond the control and understanding, both by an individual, and by the professional community and society as a whole. Rather, we observe a general disturbing sense of violation of the usual boundaries of definitions and norms. In response to the crisis of comprehension and understanding, philosophy of language and communication turns back to the idea of discursivity of human civilization and proposes to adapt and rethink the concept of possible worlds and its descriptions in the aim to renew social strategies and communications. The increasing demand for methodological support of communication activities indicates the growing significance of cabinet philosophy, in particular philosophy of language and communication. This strategy of the scientific approach will allow us to build a research relevant to the subject-transdisciplinary. Based on an analysis of history of ideas and modern Russian methodology of transdisciplinarity, the authors put forward a hypothesis in terms of the philosophy of language on the development of digital mediated discourse in a transdimensional unity and the generation of different discourses.
\end{abstract}

Keywords: transdiscourse, digital worlds, mediatization, transdisciplinarity, transborder, philosophy of language and communication

Conflicts of interest. The authors declare that there is no conflict of interest.

Acknowledgements and Funding. This research was performed according to the Development Program of the Interdisciplinary Scientific and Educational School of Moscow University "Preservation of the World Cultural and Historical Heritage".

Article history: submitted: March 15, 2021; accepted: June 10, 2021.

For citation: Kostikova, A.A., \& Spartak, S.A. (2021). Transdiscourse as a concept of digital worlds. RUDN Journal of Studies in Literature and Journalism, 26(4), 649-655. doi: 10.22363/ 2312-9220-2021-26-4-649-655

(C) Kostikova A.A., Spartak S.A., 2021

(c) (i) This work is licensed under a Creative Commons Attribution 4.0 International License https://creativecommons.org/licenses/by/4.0/ 


\title{
Трансдискурсивность как концепт цифровых миров
}

\author{
А.А. Костикова ${ }^{\otimes}$, С.А. Спартак \\ Московский государственный университет имени М.В. Ломоносова, \\ Российская Федеращия, 119234, Москва, Ленинские Горы, 1 \\ 凶akostikova04@ya.ru
}

\begin{abstract}
Аннотация. В статье представлен анализ трансформаций медиакультуры в условиях радикальной цифровизации общества. Повседневность принципиально медиатизируется и этот процесс оказывается вне управления и осмысления как отдельным человеком, так и профессиональным сообществом и обществом в целом. Мы наблюдаем скорее общее тревожное ощущение нарушения привычных границ определений и норм. В ответ на ситуацию кризиса в понимании и оценке этих процессов философия языка и коммуникации возвращается к идее дискурсивности человеческой цивилизации и предлагает адаптировать и переосмыслить концепцию возможных миров и их описаний прежде всего для решения задачи обновления социальных стратегий и коммуникации. Возрастающий спрос на методологическое обеспечение коммуникативной деятельности свидетельствует о растущем значении «кабинетной» философии, в частности философии языка и коммуникации. Такая стратегия научного подхода позволит выстроить исследование релевантно предмету - трансдисциплинарно. На основе анализа истории идей и современной российской методологии трансдисциплинарности авторы выдвинули гипотезу в терминах философии языка о развитии цифрового медиатизированного дискурса в трансмерное единство, генерирующее различные дискурсы.
\end{abstract}

Ключевые слова: трансдискурсивность, цифровые миры, медиатизация, трансдисциплинарность, трансграничность, философия языка и коммуникации

Заявление о конфликте интересов. Авторы заявляют об отсутствии конфликта интересов.

Благодарности и финансирование. Исследование выполнено в рамках Программы развития Междисциплинарной научно-образовательной школы Московского университета «Сохранение мирового культурно-исторического наследия».

История статьи: поступила в редакцию - 15 марта 2021 г.; принята к публикации - 10 июня 2021 г.

Для цитирования: Kostikova A.A., Spartak S.A. Transdiscourse as a concept of digital worlds // Вестник Российского университета дружбы народов. Серия: Литературоведение. Журналистика. 2021. Т. 26. № 4. С. 649-655. doi: 10.22363/2312-9220-2021-26-4-649-655.

\section{Introduction}

Rather, we observe in the conditions of crucial digitalization of society a general disturbing sense of violation of the usual boundaries of definitions and norms. Big Data for example is collected without understandable human supervision and, it is not only ethical or legislative challenges, but methodological philosophical challenge [1]. Digital worlds are improving very quickly in now days and tomorrow we won't realize what objects physical or virtual we meet. 
And here are the environments that we are already in with new qualities of reality or simulation its physical qualities. It seems that the difference is narrative but the concept of Transdiscourse turns the picture out: the everyday life, our work or entertainment, the politics, by the politicians themselves or threw the media, the culture and science, presented by professionals or by public - all converse to the transborder evolution of discourse.

A i m: to reconstruct the theoretical impact of Philosophy of Language and Communication in the Critical Inquiry of Mediatization of the Culture. In terms of the philosophy of language it is a development of discourse in a transdimensional unity and the generation of different discourses, suggesting the development of disciplinarity in transdisciplinarity. This new cooperation of different disciplines in the process of digital worlds constructing is overcoming of epistemological yarrow between them.

Discussion: The explanation is often given in terms of the complexity or complexity, dynamism, and unpredictability of new systems. In this regard, many functions of the systems are deformed. Russian philosophical approach on methodology of transdisciplinarity is related with the tradition of dialectical thought. Although it is obvious that such a nature of systems has already been described in dialectical concepts - that is, coming from the development and multi-level nature of systems. But the continental and analytical philosophers could add some principal basics in this understanding and give the new perspectives of describing the world. But the most important optic is presented by philosophers of Discourse [2]. In response to the crisis of comprehension and understanding, philosophy of language and communication turns back to the idea of discursivity of human civilization and proposes to adapt and rethink the concept of possible worlds and its descriptions in the aim to renew social strategies and communications. Philosophy plays an important role in integrating the knowledge and competencies of a wide range of scientific and practical branches on the basis of structuring the problem field.

Method: Historical and analytical reconstruction of theoretical interpretations of transdiscursivity and contemporary issues: strategic communication is considered as a certain way of thinking about communication as a concerning management at all levels of activity [3]. Thus, the self-definition and integrative methodic to rebuilt the scholar knowledge and practices in different areas of communication is an important issue of this research.

\section{Reconceptualization of discourse: Transdiscursivity}

On this revolutional non-antithetic philosophy of language as the key of the human culture so called "French theory" all philosophies of communication grow up: "a body can be everything" [4], outside binary and metaphysical ways of thinking [5], outside the anatomy [6] in a discursive practice [7] and etc. At the very roots - the Wittgenstein's Linguistic Turn of Philosophy. But more useful for communication studies became Foucault' and Derrida' concepts of discourse. 
It could be observed as an explanation of the current mediatization of all intellectual production that we are producing — at individual or collective level. A new letter or arche-letter, or what he then just starts calling "a letter" — is something that has no beginning, which itself is a list, which is a list both in the literal sense (such a rewriting) and some transcription. And in this regard, immediately, as you understand, the letter expands, i.e., it is an arrangement, it is how something is heard. Notice how the emphasis shifts. We don't actually have a speaker anymore, we don't have a source, but we do have a certain process of rewriting transcribing / rewriting again, you see, this time slice is immediately torn apart, as if the chronology is out of the discussion. Because, it seems clear there is no beginning of the list, there is no such chronological chain. In the case of the text, these templates are related to the manifestation of language and, above all, in writing. I.e., as an attempt to consider writing, as, for example, an internal speech, and to collide the external and internal. And we must say, all classical and actual concepts of internal speech, internal experience, it is extremely actively updated today. An attempt to escape from the direct collision of the inner and the outer, and to try by what is difficult to reduce to an unambiguous, fixed, in the sense of a certain manifestation, usually performative, i.e. external, to bring under some explanation what has always been considered to belong to the inner.

With the discourse analysis, we run through media materials i.e. how a particular term works, and the computer already counts all the connections, taxonomic maps are compiled. It is clear that the discourse analysis appears, undoubtedly, from philosophy, but it becomes an applied field of research that requires its own philosopher for interpretation. Discourse analysis is rather a tool of political philosophy and the history of political thought, because by and large, the discourse analysis of philosophical texts does not provide a reconstruction of the mass character of the use of terms. Because here, too, the history of ideas and the history of the ideas of philosophy, that is, no matter how we focus there, remains free from thus method.

This does not mean that you cannot use it on these texts, but still you will only get what one author has, and this is obvious even without quantitative calculation, since it is explained in a certain way - how as a rule, philosophical texts give an appropriate introduction, some propaedeutics in the use of terminology. The difficulty was precisely that the concrete rational mechanisms on which modern science is built - this is Galilean modeling, reasoning by analogy - it just very often involves a departure. And, paradoxically, a very important plot here, which in many ways, if it does not bring us closer together, then it builds a single field of conversation between analysts and structuralists this is of course the role of a metaphor.

The mediatization of the culture let us step back to metaphorical and polysemantic language. The language reappears completely different — and it is no more the only one, it is something in a complex eternal process of selfconstruction. Like the Möbius line presented by J. Lacan in his variant of topological metaphors. And Derrida refers to M. Heidegger that gave him this 
sense of language. That is no questions about boarders but the search of different ways to transgress the traditional rational instrumental frontiers of meanings. Thus, we found in the use of notion of discursivity the very deep need of rethinking the methodology of science itself, the need of new language of scholar research.

\section{Reconceptualization of disciplinarity: Transdisciplinarity}

Russian philosophy of science has a long tradition of methodological inquiries. In the structure of professional education in philosophy the link with the science was ever very strong and significant. And vice versa - the philosophy and methodological explanation has a powerful meaning for academic research in natural sciences.

The challenges of modern innovative scientific projects and the mediatization of academic science itself push to revise the terms of disciplinarity: "It is necessary to look at science as a whole as an innovatively reflexive self-organizing environment, the evolution of which obeys the general laws of "upward" evolution in the direction of increasing complexity, the emergence of new differences and the preservation of the former various organ-like symbioses (autopoiesis)" [8]. Expert discussion of the situation in Russian academic science due to the changes in the academic policy since 2016 allowed one to state that the new terms as transdisciplinarity reflects an increasingly significant integration of specific scientific communications. They became already more flexible and relevant in the conditions of new innovative strategy. Russian philosophical approach in methodology of transdisciplinarity is related with the tradition of dialectical thought. Although it is obvious that such a nature of systems has already been described in dialectical concepts - that is, coming from the development and multi-level nature of systems. And we can see the improving and differentiations of this understanding [for example, 9]. It is useful to underline that the reaction to the new appeals make turn the philosophy back - to Kant - for example or to the philosophy of $20^{\text {th }}$ century discussing the previous to Artificial Intelligence topics of new virtual world - Technik itself. And the philosophical critique of technical society provided by Husserl, Simmel, Heidegger, Jaspers and others throw the in-between new age of science - with Bachlaire and Simondon gave us the example of the new approach in inquiry. All assessments in science have to be long-term investigations with some special organizational efforts and not a single experience with one effect or result. It has to be a long way of construction and reconstruction of the special language of inquiry. And by and threw this language - new subjects of inquiry and new scientific teams.

The performance of the united process of self-construction and selfidentification is finally the only one subject of understanding and theorizing. That is why the philosophy of language is so important not only for analytical philosophical researches concentrated in logical theories of meaning and senses but for humanities. Performativity of individual, personal is the main theoretical problem of contemporary philosophy (for example, this is one of the central 
concepts of Judith Butler's gender theory that she borrows from John Austin), understood in the tradition of analytical philosophy: action, articulation and meaning.

Human society and culture in all its historical forms produces and reproduces always this kind of uncertain unstable and nonlogical relations in uncertain unstable and nonlogical language senses. Floating signifying is the processual basis of the culture [10]. And there is no signified strict and unchangeable in human culture. It could be an ontology without hierarchy, without center, could be a description without strict rules, could be a human society without policy — and the nature of human bring is already prepared for those conditions. We have already this experience and it is the basic one for all other our live experience - it is our freedom in sense of creativity, it is the lability of our personal relations, it is our biological algorithms and energy for all ours achieves.

As the French philosopher M. Merleau-Ponty has successfully formulated it, the most important task of metaphysics of the 20th century is to overcome its antithetic both in the answers to the "eternal" philosophical questions, and in their statement. The traditional alternative of the common and single, individual and society, possibility and reality, project and its realization, new and old, intuition and rationality, faith and reason, expression and expressive means, male and female, finally, becomes in the modern philosophy, especially gender, the theme of historical and philosophical criticism, in relation to which a new style of philosophical thinking is formed [11]. This is the search for a third, no alternative way. The basis of this approach is the fundamental difference of all, including philosophical, postmodern culture, considering the person, his perception of the world and the world in a close relationship [12]. Thus, the concept of transdisciplinarity can be generally defined as a more methodologically differentiated stage of the evolution of language of understanding that give to the science the opportunity of long-term complex flexible systematic interactive innovative scholar research.

\section{Conclusion}

The communication system has always been one of complex types of systems, as it is conceptualized by Russian philosophers of methodology of science. And its digitalization has not simplified it, but has made its complexity and dynamism visible. Transdiscourse reverses the status of constructed digital worlds, they cease to be secondary, they turn out to be primary. The idea of transdiscursivity, proposed first of all by so called French Theory, could be a support for discourse analysis of mediatized current everyday culture.

The philosophy of language and communication can play an important role in integrating the knowledge and competencies of a wide range of scientific and practical branches on the basis of structuring the problem field. This strategy of the scientific approach will allow us to build a research relevant to the subject transdisciplinary. Thus, the analysis of history of ideas and modern Russian 
methodology of transdisciplinarity confirms the research hypothesis put forward in the article: in terms of the philosophy of language the digital mediated discourse develops in a transdimensional unity and the generation of different discourses.

\section{References / Библиографический список}

[1] Kostikova, A., Segal, A., Sorina, G., \& Spartak, S. (2017). Big Data: a loop or a challenge for human morality: mapping Russian tradition in philosophy and methodology. Russian Journal of Communication, 9(3), 252-262.

[2] Kostikova, A. (2018). French theory and language criticisms. International Multidisciplinary Scientific Conferences on Social Sciences and Arts SGEM, 5(4.1), 373-378.

[3] Shilina, M.G. (2018). Innovation Driven Strategic Communication: Towards a Holistic Approach Public administration. Electronic bulletin, (66), 44-59.

[4] Deleuze, G. (1988). Spinoza: Practical Philosophy (p. 127). Transl. R. Hurley. San Francisco.

[5] Derrida, J. (1976). Of Grammotology. Transl G. Spivak. Baltimore and London.

[6] Lacan, J. (1977). Ecrits. A Selection. Transl. A. Sheridan. London.

[7] Foucault, M. (1972). The Archeology of Knowledge and the Discourse on the Language. Transl. A. Sheridan, NY.

[8] Archinov, V.I., Gorokhov, V.G., Budanov, V.G. et al. (2016). The problem of transdisciplinarity in the context of Russian academic reforms. Philosophy of Science and Technology, 21(1), 5-35. (In Russ.)

Аршинов В.И., Горохов В.Г., Буданов В.Г. и др. Проблема междисциплинарности в контексте реформ российской науки. Материалы «круглого стола» // Философия науки и техники. 2016. Т. 21. № 1. С. 5-35.

[9] Sorina, G.V. (2020). Bajanov. Brain - Culture - Society. Kantian program in cognitive sciences. Voprosy Philosophii, (2), 211-213. (In Russ.)

Сорина Г.В. В.А. Бажанов. Мозг - Культура - Социум. Кантианская программа в когнитивных исследованиях // Вопросы философии. 2020. № 2. С. 211-213.

[10] Simondon, G. (2012). Du mode d'existence des objets techniques. Paris, Aubier, 1958; dernière réédition corrigée et augmentée. Paris: Flammarion.

[11] Kostikova, A.A. (2013). Postmodernism: A feminist critique. Metaphilosophy, 44(1-2), 24-28.

[12] Merleau-Ponty, M. (1945). Phenomenologie de la perception (p. 9). Paris.

Bio notes:

Anna A. Kostikova, $\mathrm{PhD}$ in History of Philosophy, Associate Professor, Head of Philosophy of Language and Communication Department, Faculty of Philosophy, Lomonosov Moscow State University. ORCID: 0000-0002-5471-5306; e-mail: akostikova04@ya.ru

Sergey A. Spartak, PhD in Political Sciences, Senior Lecturer, Faculty of Philosophy, Lomonosov Moscow State University. ORCID: 0000-0002-8862-703X; e-mail: sspartak@ya.ru

\section{Сведения об авторах:}

Костикова Анна Анатольевна, кандидат философских наук, доцент, заведующая кафедрой философии языка и коммуникации философского факультета МГУ имени М.В. Ломоносова. ORCID: 0000-0002-5471-5306; e-mail: akostikova04@ya.ru

Спартак Сергей Андреевич, кандидат политических наук, старший преподаватель философского факультета МГУ имени M.B. Ломоносова. ORCID: 0000-0002-8862703X; e-mail: sspartak@ya.ru 